\title{
Movement/ing Provocations in Early Childhood Education
}

\author{
Nicole Land and Ildikó Danis
}

Nicole Land is a $\mathrm{PhD}$ candidate, sessional instructor, and research assistant in the School of Child and Youth Care, University of Victoria, where she also works with early childhood educators as a pedagogical facilitator. Drawing on feminist science studies and feminist new materialist perspectives, she is interested in attending to, and experimenting with, how fat(s) and muscle(s) can be practiced, move, and matter in early childhood education. Email: nland@uvic.ca

Ildikó Danis is an early childhood educator at University of Victoria Child Care Services. She has a degree in early childhood special needs education from Georgia State University, Atlanta, and experience in the Canadian, US, and Hungarian educational environments. Her interest in the complex and inclusive ways of forming "natural childhoods" spurred her curiosity about children's relations with place and everyday, natural materials. Her focus on child-material relations and movement pedagogies is motivated by a commitment to attending to stories and events that evolve by chance in the themes of children's relations with other species, with the material world, and with place. Email: idanis12@uvic.ca

Drawing on an inquiry-based project focused on experimenting with movement in Canadian early childhood education, this article imagines how educators might think (with) movement pedagogically. The authors detail our practices of pedagogical inquiry, confront contemporary movement-related policies and pedagogies in Euro-Western Canadian early childhood education, and discuss three encounters with movement: (1) creating conditions with movement(s); (2) movement does...; and (3) attending to uncommon movements. We conclude by gesturing toward the uncertain, contingent, and generative potentialities of thinking with movement in early childhood education.

Keywords: movement, pedagogy, physical activity, physical literacy, early childhood education
We removed everything from the centre space of the child care centre. Everything. The basket of books, the green race car track, the toddler-sized wooden kitchen furniture, the neatly stacked lunch table chairs-even the futon was muscled out of the room. Allaying our surprising discomfort with the vastness of the space, we gathered some cherry blossoms from the yard and scattered their damp petals across the floor. Our provocation for the morning was to intentionally foreground motion in early childhood education practice by focusing on how we might generate movement purposefully with children. We hoped to think movement beyond our familiar ways of moving by seeking movements unencumbered by the scaffolding of familiar movement materials such as soccer balls or jungle gyms. We wanted to experiment with movement pedagogically (Rotas, 2015), engaging the tensions, productivities, and pauses of movement. We anticipated an abundance of movement within our indoor space and discussed how we might engage (with) running bodies or draw exuberant explorative movement into intentional engagements within the space. We were startled by how deeply difficult movement can be and how demanding movement is of our pedagogical response-ability (Haraway, 2015).

As part of an ongoing inquiry-based research project into pedagogical practices at a child care centre in British Columbia, Canada, a collective of educators, researchers, children, and families have been imagining how early childhood education pedagogies and practice might adequately respond to, or engage with, the complex, contested, and politicized worlds of contemporary childhoods. We-Ildikó (an early childhood educator) and Nicole (a doctoral student pedagogista) - position our pedagogical practices within a commonworlding ethic (Pacini-Ketchabaw, Taylor, \& Blaise, 2016) and cultivate a sustained engagement with "the broader, relational contexts that children inhabit as integral parts of the universe" (Blaise, Hamm, \& Iorio, 2016, p. 2). Our inquiry work launches from a politicized attention to the contested ethical dimensions of pedagogy, wherein a necessity to confront ongoing settler colonialism (Clark, PaciniKetchabaw, \& Hodgins, 2014; Nxumalo, 2016), a concern with the infiltration of neoliberal paradigms within education (Ashton, 2014; Osgood, Scarlett, \& Giugni, 2015), and an impulse to be response-able to contemporary Euro-Western anthropogenic forces (Taylor \& Pacini-Ketchabaw, 2015) inform our practices.

In the furniture-free space of the child care centre, we began to put our pedagogical practice to work with movement. Engaging with 
movement and pedagogy has not been an encounter with extreme free play. Rather, we work to be deeply intentional with movement with the children: We approach movement as an ethical, politicized, and intra-active engagement with our complex and fractured (un) common worlds. In our inquiry work, we wonder what movement can do with bodies, with pedagogy, and with children's learning, as opposed to investigating how children can learn movement. We imagine what movement relevant to the increasingly polarized, colonized, and anthropomorphized spaces of Euro-Western childhood might demand and produce, and how moving might engender a response to the normalizing, regulatory, and outcome-oriented movement pedagogies that typically inhabit early childhood education. We attend to how the movements we enable in practice are productive of engagements with worlds and how pedagogical practices shape, propel, and stall children's encounters with movement.

In this article, we articulate our inquiry-based experiment with movement in early childhood education, imagining what might be produced when we think with movement carefully, critically, and pedagogically. We begin by detailing our practices of pedagogical inquiry (Lenz Taguchi, 2010; Pacini-Ketchabaw, Nxumalo, Kocher, Elliott, \& Sanchez, 2015), then confront the current context of physical activity policies and pedagogies in Euro-Western Canadian early childhood education. Next, we discuss three encounters with movement: (1) creating conditions with movement(s); (2) movement does...; and (3) attending to uncommon movements. Finally, we conclude by imagining the potential consequences of our work with movement, gesturing toward the uncertain, contingent, and generative potentialities of thinking with movement in early childhood education.

\section{Moving with Pedagogical Narrations}

We craft this article as our process of thinking movement (as) pedagogies. Adopting a methodology of relational materialist pedagogical inquiry (Hultman \& Lenz Taguchi, 2010), we think with pedagogical narrations (Hodgins, 2012; Pacini-Ketchabaw et al., 2015). Gathering pedagogical documentation, we generate narrations as collaborative critical encounters with the uncertain complexities of practice and pedagogy (Berger, 2015; Hodgins, Kummen, Pacini-Ketchabaw, \& Thompson, 2013). We take seriously the view that pedagogical narrations are "a process by which educational experiences in early childhood settings are narrated and made visible in the public realm" (Berger, 2010, p. 58). Our inquiry practices are imperfect, experimental, and under continual revision (Springgay \& Rotas, 2015). This article works to make this ethic of uncertainty, and our pedagogical discussions, visible as an ongoing dialogue between Ildikó and Nicole.

Importantly, our inquiry work is concerned with consequence (Dolphijn \& van der Tuin, 2012) and attends to generativity—we seek a "re-imagining of what method [and pedagogy] might do, rather than what it is or how to do it" (St. Pierre, Jackson, \& Mazzei, 2016, p. 105, italics in original). We conceptualize this article as a provocation, rather than a framework to be wholly applied to other sites of practice (Pacini-Ketchabaw, Kind, \& Kocher, 2016). We hope we have created an impulse for inquiry that is precise but not prescriptive, that is tentative and accountable, experimental and consequential.

\section{Movement and Euro-Western Canadian Early Childhood Education}

We begin our engagement with thinking movement pedagogically by encountering predominant frameworks for conceptualizing movement in mainstream Canadian early childhood education policy and practice. After tracing how "movement" is subsumed into "physical activity" and "health" in policy documents, we interrogate mainstream movement pedagogies in Canadian education to make visible how these policies translate into strategically regulated pedagogical practices.

\section{Movement in British Columbia Early Childhood Education Policy}

In British Columbia, early childhood education practice and pedagogy are guided by three central documents: the Child Care Licensing Regulation of the Community Care and Assisted Living Act (Government of British Columbia, 2016) details operational and training requirements for early years practice; educator development and professional competencies are outlined in the Child Care Sector Occupational Competencies (Government of British Columbia, n.d); and curriculum development and pedagogical practices are guided by the British Columbia Early Learning Framework (Government of British Columbia, 2008).

The Child Care Licensing Regulation gestures toward movement-related practices through concepts of "health" (Part 4, Division 1.46), "physical development" (Schedule G, Section 44.1), "physical growth" (Part 4, Division 1.43), and "large and small muscle skills appropriate to each child's level of development" (Schedule G, Section 44.1). "Movement" is explicitly integrated once into 
this document (Schedule G, Section 44.2). Within the Child Care Sector Occupational Competencies, movement is referred to as "small and large motor development" (Activities 1C.1) and is mentioned in relation to the requirement for programming to address children's developmental and educational "needs" to "ensure health" (Activities 1C) and an attention toward "development of the whole child" (Activities 2A.3). "Movement" appears once in the Child Care Sector Occupational Competencies (in a footnote) related to the implementation of programming that includes a variety of learning opportunities for children (Activities 2B.1). The British Columbia Early Learning Framework integrates movement as a form of expression (p. 9) and as communicative engagement (p. 30), and argues that educators should consider how movement is supported within different environmental designs (p. 14).

We contend that the limited presence of the term "movement" in the Child Care Licensing Regulation and Occupational Competencies is symptomatic of a carefully politicized transformation of movement into physical activity that is enabled by intertwining majoritarian Euro-Western early years policies with the contemporary Canadian obesity apparatus. Our argument is consistent with numerous critical analyses in post-developmental early years theorizing that make visible the politicized character of early years policy while probing the mechanisms by which policy enacts settler colonialism (Nxumalo, 2015) and neoliberal governance (Lenz Taguchi, 2011; Moss, 2016) through techniques of anthropocentrism, individualization, normativity, and the favouring of universalized and predictable developmental trajectories (Blaise, 2014; Kummen, 2014; Taylor, Blaise, \& Giugni, 2013; Pacini-Ketchabaw \& Nxumalo, 2015).

Coupled with anxieties about the prevalence of obesity — an "epidemic" that is constructed and maintained by neoliberalism, capitalism, and settler colonialism (Beausoleil \& Ward, 2010; Evans \& Davies, 2012; Rice, 2016) - the regulatory tendencies of mainstream early years policies become increasingly visible. While an exhaustive analysis of the functioning of the Canadian obesity apparatus is beyond the scope of this article (please see Ellison, McPhail, \& Mitchinson, 2016; Petherick \& Beausoleil, 2016; Rail, 2012), we draw inspiration from critical obesity studies, fat studies, and critical fitness studies to argue that early years policy is built to sustain an obesity-perpetuating system of bodied governance that oppresses undesirable "fat" bodies while concurrently creating the conditions to make these bodies (which tend to be already entangled with racialized, gendered, or ability-related oppression) increasingly "unhealthy" (Rich, 2011). Echoing the assertion that contemporary conceptions of health emerge from the conflation of Euro-Western notions of citizenship, morality, and productivity with physical wellness (Gard, 2016; Guthman, 2011; LeBesco, 2011), we argue that the inclusion of physical activity in early years policy is framed as an antidote to unhealthiness, where "unhealthy" serves as a proxy for " not normal." As such, physical activity foregrounds neoliberal technologies of normativity, individualization, and universalized developmental trajectories (Elliott, 2016; Evans, 2010; Rice, 2007), technologies that create "unhealthy" bodies and then continually remark noncompliant, nonnormative, undesirable bodies as unhealthy. We contend that crafting movement as physical activity in early childhood education works to discipline and regulate "unhealthy" bodies, which reaffirms systemic oppression related to (un)health, which then delimits acceptable ways for educators and children to do movement: Movement becomes physical activity, becomes policy, becomes health, becomes normal and legitimate bodies.

\section{Pedagogies of Movement in Canadian Education}

In Canada, the concept of physical literacy - the ability to "move with competence in a wide variety of physical activities in multiple environments that benefit the healthy development of the whole person" (Mandigo, Francis, Lodewyk, \& Lopez, 2009, p. 28) -is a central figure in pedagogies of physical activity. Physical literacy pedagogies in Canada tend to be rooted within developmental conceptions of childhood that trace early movement competence into sustained physical fitness through adulthood, while parsing movement into independent components of literacy (please see the Long Term Athlete Development Model from the Sport for Life Society [2016] and the division of movement into locomotor, object control, and balance skills). That the fundamental movement skills of physical literacy be quantifiable and subject to evaluation is of utmost importance to physical literacy pedagogies (Tremblay \& Lloyd, 2010) because these pedagogies are concerned with effectively preempting the development of unhealthy adult Canadians and the economic and social consequences the obesity apparatus (and, therefore neoliberal governance) assigns to fatness and inactivity.

In early childhood education in British Columbia, physical literacy tends to interject in pedagogy as prescriptive activity lesson plans (e.g., Healthy Opportunities for Preschoolers by Temple \& Preece [2007] and Healthy Beginnings for Preschoolers 2-5 from the Chronic Disease Prevention Alliance of Canada [n.d.]), authoritarian guidelines for physical activity type and duration (e.g., Canadian Physical Activity Guidelines for the Early Years by the Canadian Society for Exercise Physiology [n.d.] and ParticipACTION Early Years Guidelines [2016]), and "objective" evaluative mechanisms to identify children who may be in need of physical literacy support (e.g., Canadian Assessment of Physical Literacy from the Healthy Active Living and Obesity Research Group [2014-2016]). Numerous post-developmental analyses of physical activity pedagogies make visible how physical literacy discourses enact governmentalities of citizenship, individualism, responsibility, and aesthetics (Evans \& Rich, 2011; Larsson \& Quennerstedt, 2012; Lundvall, 2015; Nyberg \& Larsson, 2014). We are concerned here with the consequential extensions of these pedagogies (Kummen, 2011) whereby physical 
literacy marks some forms of movement as good/legitimate/healthy (or "physical activity") and others as bad/nonproductive/useless.

Physical literacy pedagogies perpetuate regulated and outcome-oriented engagements with movement by enacting clear, seemingly objective demarcations between "physically active" and "unhealthy" movements:

The basic movement skills ... can be developed through the following four activities [athletics, gymnastics, swimming, skating]. In combination, they provide a base for all other sports... Without the basic movement skills, a child will have difficulty participating in any sport. For example, to enjoy baseball, basketball, cricket, football, netball, handball, rugby and softball, the simple skill of catching must be mastered. (Long Term Athlete Development Model, Sport for Life Society, 2016, p. 24)

Physical literacy delimits possibilities for movement by positioning the acquisition of specific, measurable skills as a developmental imperative ("without movement skills, a child will have difficulty"), clearly describing the required skills and the activities that must be offered to achieve those skills ("locomotor, object manipulation, and balance skills can be developed through athletics, gymnastics, swimming, and skating"), and rooting the attainment of these skills in existing narratives about healthy, happy, normative Euro-Western childhood development ("to enjoy baseball, catching must be mastered"). These physical literacy pedagogies draw on evidence-based knowledges and deploy techniques of individualization, normativity, responsibility, and citizenship (Markula, 2014; Markula \& Kennedy, 2011; Wiest, Andrews, \& Giardina, 2015) to assert the legitimacy of specific governmentally and developmentally approved forms of movement over others ("now that we've taught this child to catch a ball, they have the skills to be a physically fit [white, able-bodied, cis-gender], healthy [inexpensive], and active [attractive] adult [long-term consumer]"). Physical literacy pedagogies do not attend to the movements that are intentionally excluded, or inadvertently erased, by the regulated, outcome-oriented reduction of movement to physical activity.

\section{Foregrounding Movement in Practice}

Our experiments with movement enact an ongoing response to existing policies and pedagogies of movement, but do not beget a wholesale negation of these practices. We do not wish to argue that physical literacy pedagogies are (always) bad, but we do assert that these are specific, contextual, and consequential mechanisms of settler colonial and neoliberal governance that impose problematic boundaries on the possibilities for movement. In the following encounters with movement, we dialogue with pedagogical documentation to consider possibilities for thinking with movement with pedagogy in early childhood education.

\section{Movement/ing Encounters}

\section{Creating Conditions with (Tree-Cookie-Lung) Movement}

Nicole: Throughout our inquiry, we experimented with different configurations of the space. We removed the furniture, investigated how we can move with lighting and shadows, tested how we might move with textiles and tree cookies (wooden cross-sections cut from a tree), and worked with hanging streams of paper. Movement responded to these provocations in different ways as we changed tempo, paused, tracked across the floor, or flipped upside-down against walls, and felt differently (un)familiar. We attended to how the material conditions of movement mattered, of how moving with a certain tree cookie or shadow created an emergent set of possibilities for moving. But this attention to the consequences materials held for movement seemed inadequate when we debated what might be happening with movement - the conditions that enabled/constrained movement seemed to extend beyond simple translation, where a tree cookie might generate one movement and a shadow another. We also burrowed into a more expansive, less readily measurable, consideration of movement. We became concerned with how we create conditions with - not for-movement. Questions of how we transformed (with) more than the physical conditions of the room led to an attention to how we engaged with the space and moving within that space, at the same time. I wonder what this shift from noticing how different materials produced different movements, to attending to how materials and movement create together might mean for thinking movement pedagogically?

Ildikó: I tend to think that removing physical "barriers" from the environment (removing all the furniture, objects, and materials that were always there before, those items that the children got used to having around) and educators "being on board" with the experiment resulted in the formation of unexpected or not-yet-seen movements exhibited by children - which were not new, in the sense they were not movements that children could never do before. What was interesting and inspiring was how children got to the performed moves in their own unique ways, and how it was supported by the educators. There wasn't a set goal for the children to achieve, and movements were not performed by educators for the children to mimic or copy. How can educators better empower children to recognize their own 
individual moves, moves evoked by themselves, by their own curiosity or their responsiveness to the environment around them? What moves are children drawn to more or attracted to over others? Why?

For example, tree cookies perched on children's bodies. I remember hearing children's breathing and watching them observing their own bellies moved by the air they breathed in and out. So much was there in those moments. Toddlers willingly lying still on the floor, controlling their breathing. Discovering that if they laughed, the cookies would slip off their bellies.

Nicole: I am taken by your point that movements we noticed were not new "in the sense they were not movements that children could never do before." That is, we did not create a magically unique set of conditions for movement that allowed for brand new, totally inventive movements to happen. Rather, movements created with/through/in our inquiry were made perceptible, or were generated, differently than how movement is typically performed in early childhood. This has substantial implications for thinking movement pedagogically, because it expands the scope of what "counts" (or interjects) in movement pedagogies. It is not simply a question of reconfiguring the spatial or material conditions of movement, but of reimagining the movements that can be perceptible in early childhood.

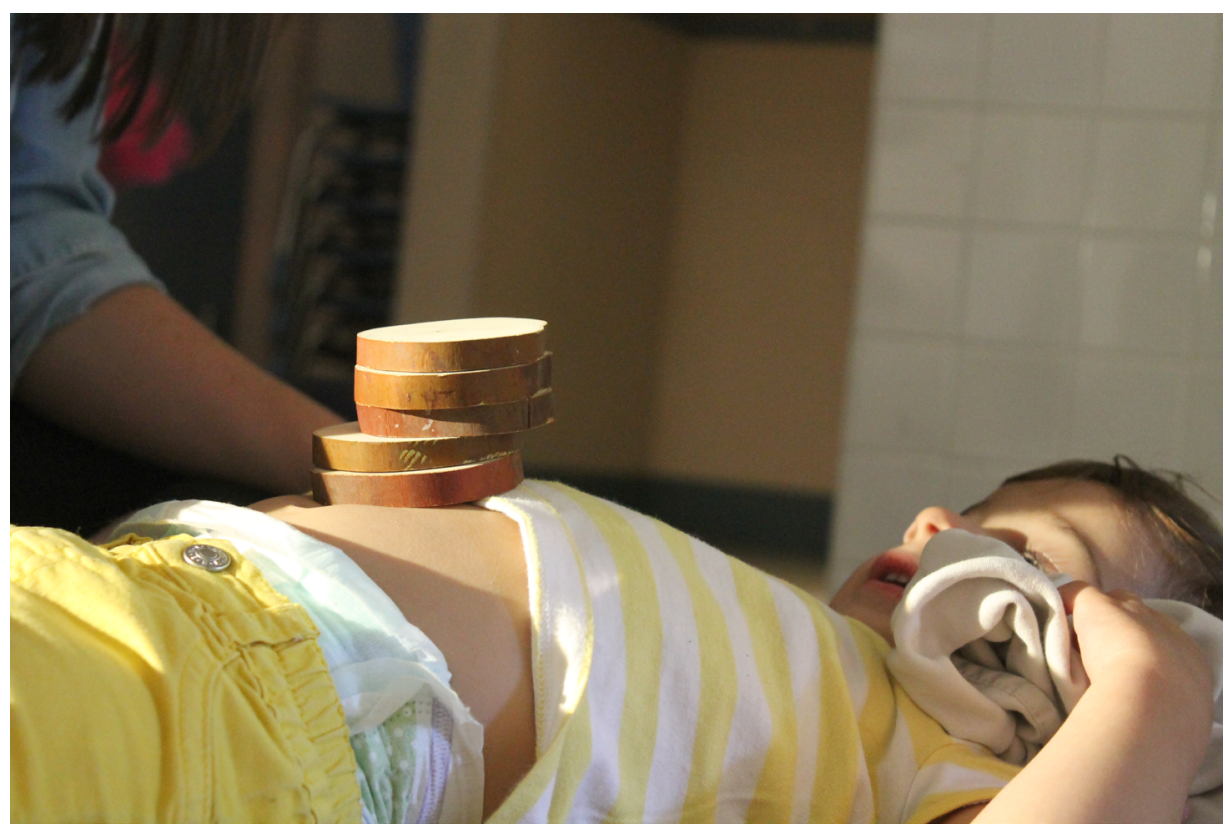

Figure 1. How do we move with tree cookie-lung-movements?

For example, we emptied the entire space on numerous consecutive inquiry days, but I was continually frustrated by the extreme variation in potential movements that emerged over those days. Some days, we noticed motion that pulled at the borders of familiar movements, such as when children experimented with tree cookies balanced on bellies. Other times, children ran in repetitive circles. If I consider this variation in terms of the conditions we created for movement, I am left assigning this variation to individual children's energy level or desire to recreate "fun" movements: If the space was the same, I have to account for this difference in children's behaviour and in the human bodies in the room. If I root this movement variation within an expansive consideration of movement and pedagogy, I understand that running is perceptible through physical activity discourses, while noticing how tree cookies push back against lungs as children inhale and exhale is absent from these knowledges. Tree-cookie-lung-movement did not simply "happen" when we laid out the tree cookies, but was created with movement, with a politicized ethic enacted by educators in the space to reimagine the possibilities for movement. Tree-cookie-lung-movement does not emerge spontaneously, but is generated with deeply intentional politicized movement pedagogy.

Ildikó: Nothing could, and did not, happen without creating dialogue with movements. Children, educators, and pedagogistas were in a situation where every bit of movement, moving of anything — sounds, gestures, body language, positions, response-moves — was so visible that it was impossible to not notice even the slightest motion or variation. Because of the emptiness of the room, it was interesting to experience how careful educators were with our words. 


\section{Movement Does... (Body-Blanket Tumbles)}

Nicole: This movement-dialogue-language connection you are discussing extends the politics of thinking movement pedagogically into a consideration of how we conceptualize the concept and consequences of movement. It matters if we use the words "movement" or "physical activity," but simply swapping our language does not constitute a reconceptualization of movement in early childhood education. How we theorize movement is of great pedagogical import. Philosophical debates about what movement is or what constitutes movement are fascinating, but within our inquiry work, our impulse would be to ask what movement does: How does movement produce? How do the consequences of movements matter?

As I turned back into the room after carrying the final stack of chairs to the yard on the very first morning of our inquiry, I felt this quote by Erin Manning (2014) push forward in my brain: "A philosophy of the body never begins with the body; it bodies" (p. 163). That is, bodies and movement are not independent entities that preexist one another, but are ongoing, emergent, connective, and productive. Bodies do not "do" movement; movement happens with bodies; bodies matter with movement. This ethic flips physical literacy pedagogies on their heads, because it emphasizes that coming to movement with an understanding that "I am going to jump and a jump looks like this" is not movement, but repetition or replication. This is not to say that any idea of jumping is not relevant to early childhood, but that preformulated notions of jumping produce different consequences than other understandings of movement. Repetitious or replicated movements do things in early childhood education, as do other types of movement. Physical activity discourses and tree-cookie-lung-movements produce different engagements with bodies, materials, and politics. Thinking movement pedagogically requires that we consider how different consequences produced by different movements might be relevant to children's lives.

Ildikó: I am inspired by this quote: "We engage in thinking beyond instrumentalism, which reduces things to surface qualities and functions and treats materials as merely what mediates learning and developmental processes" (Pacini-Ketchabaw, Kind, \& Kocher, 2016, p. 3). In our inquiries with movement with toddlers, we engaged in thinking beyond instrumentalism. Removing all that was able to be removed from the indoor environment, we set aside our and the children's relational connections to furniture, objects, toys, and materials. It was an attempt to see what bodies and gazes could do with the "only (?)" other thing left to do (we imagined), which was moving. One of the goals for us with movement was to reassemble early childhood spaces, to (in thinking with movements) to strip down the environment to a bare minimum. We found that relationality is central to encounters with movements.

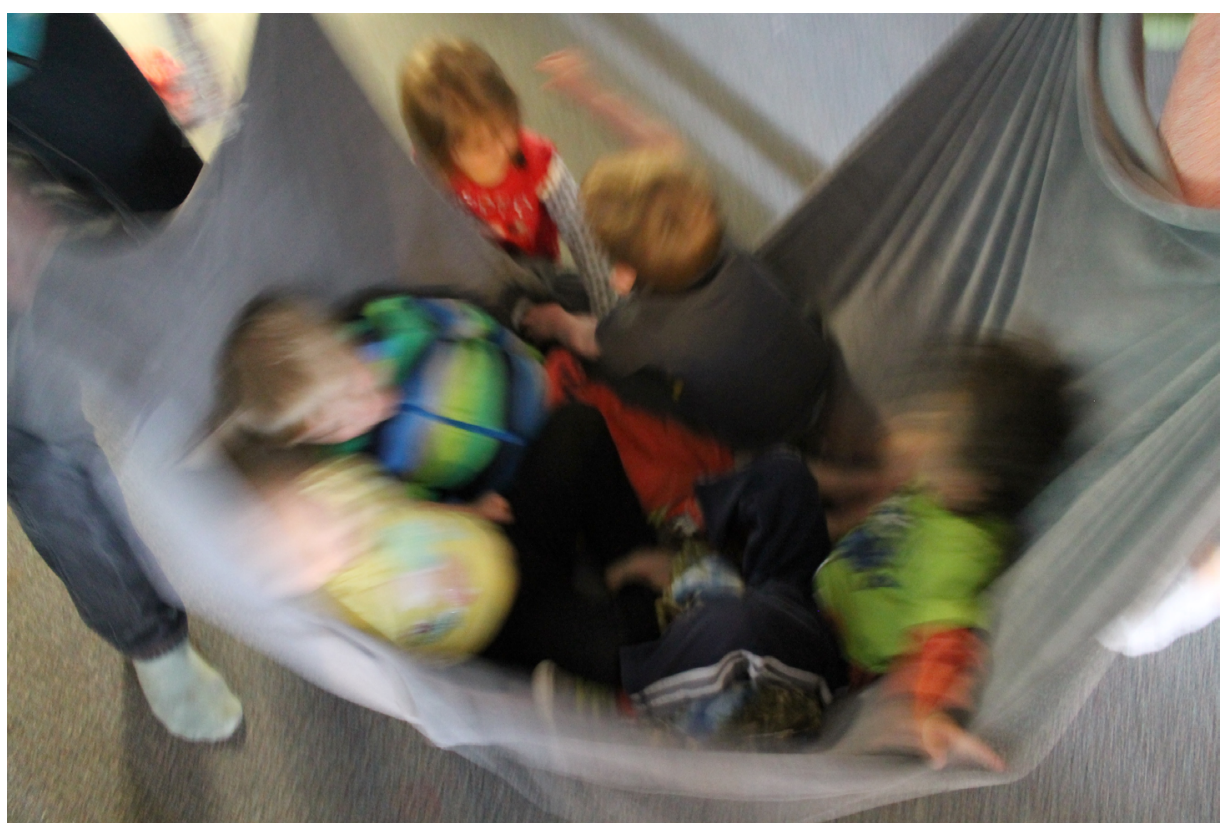

Figure 2. How does movement do (with) relationships?

Nicole: It seems we are noticing how movement does relationships, but also that these relationships are not outcome oriented. Rather than purporting that we need, for example, to build trusting, safe relationships with children to effectively teach balancing skills, we are attending to how moving is relational, how movement is a process and practice of negotiation, connection, co-creation, and experimentation. I am reminded of a moment where many children piled into a large blanket, which was pulled, lifted, and tousled by adult-bodies. This is an incredibly textured moment for me-it was so productively tumultuous as elbows bumped into ribs, the 
blanket grew a hole, biceps became exhausted. Physical activity pedagogies can make meaning of this moment as a site of goal-directed relationships, where children resolved disputes over elbow space and learned spatial awareness in relation to other bodies. However, attending to this moment to consider how movement does relationships produces this moment otherwise: Body-blanket-tumbling movement(s) are a contested, contingent co-creation with movement, where parsing one elbow from another becomes irrelevant as the movement generates each body, together (Lenz Taguchi, Palmer, \& Gustafsson, 2016). This moving-relationship is not measurable, but is productive of future possibilities for moving-relationships.

Movement doing relationality is incredibly political. Jackson (2016) articulates "the backflip as an ontology of movement" (p. 183), exploring motion as an explicit engagement with politicized, contested forces and milieus. Jackson argues that the backflip is communicative, but as expansive and distributed connectivity, where communication is not necessarily literal or straightforward (or just between human bodies), but is speculative and expansive and connective and timely — and always political. Movement is connective, not because we make it so or create the conditions for it to be understood relationally, but because it does relationships. We keep saying how "we" reconfigured the space by removing the furniture, but perhaps the rearticulation of the space did not pause there, and is continually (re)done through moving relationships. The idea that we might plan for movement becomes complicated: How can we anticipate, but not preempt, movement as it does relationship(s), such that we can be purposeful in our engagements with the politics of movement, but not prescriptive?

Ildikó: When I really felt the connection with children were those moments where moves that we discovered together returned. Some of the most fascinating moments were when educators' and children's histories with movement met up. Children's ways of evoking moves they had already exhibited before in a different context met with moves that educators discovered in themselves, either by recalling a long forgotten move or remembering with excitement their movements from their earlier lives.

An ethical movement relationship between children and their educators - that is, one in which both children and adults have the right to discover and build, or perhaps, in the case of the educators, pause, hold on - and their already happening practices of moving. It is a process, a delicate encounter, often full of frictions. Movement is a process of discovering, rediscovering, and, most importantly, negotiating the "truths" communicated by different movements, with the necessity of connecting through different movements.

\section{"We Got Grounded": Attending to Uncommon Movements}

Ildikó: Throughout our three month-long movement provocation, more and more and different materials were declaring their presence in the environment. It was very visible that the earlier experimental and differential encounters with movement, which were often slowed and/or captured the velocity of new assemblages of movements, were a cogenerated experience.

For example: the feet. With no materials to engage with, we discovered a different agency or force with the children. We got grounded. All sorts of things began to happen with and around our feet. In no other situation before I have seen children interrogate and experiment with moves that originated from moving their feet, toes, legs. Again, there were maybe no new movements discovered, but there were certainly new ways of finding, paying attention to, and being with moves that were evoked by "being grounded."

Nicole: With "getting grounded," we are starting to talk about the complexities of politically, and pedagogically, attending to movement. "Getting grounded" invoked, in our inquiry, a mode of attending to bodies, spatiality, and co-creation. As we engaged with movement pedagogically, we noticed that movement was drawing hands and feet toward the ground, while we worked to extend our attention toward what this different arrangement of bodied-space might produce and why it might matter. Physical activity pedagogies might interpret the pulling of hands toward the floor as children exploring their bodies in space in order to develop gross motor skills, emphasizing the agency of the child putting their hands on the floor. We oriented toward how this drawing of hands to carpet reconfigures the possibilities for moving in early childhood education, which involves attending to the expansiveness of how movements unfold. Here, thinking movement with pedagogy involves actively attending to the other-than-human agencies and intensities that matter with movement.

When we attend to movement as something done only by/with/from/through human bodies, what happens? It seems, in our discussions thus far, that we have been noticing relationality and connection and generation and conditions with bodies. I wonder if this is an adequate movement ethic for contemporary Euro-Western education? Rautio and Jokinen (2015) enact a "snow pile children" ethic whereby

snow pile children are not only individuals and not only humans, rather one clustering and temporal subject which has one collective more-than-subject voice. This voice screams both "I am not here (in the way that you think I am)" and "let me be." (p. 13) 
Attending to snow pile children marks a register of coextensiveness, where pedagogy responds to momentarily perceptible enactments of more-than-human bodies and their consequences. This proposition brings together our encounters with generating conditions with movement and interrogating how movement does relationality to make clear that thinking movement pedagogically demands a focus beyond only human bodies. The how of this attentiveness is a provocation I will carry into our future movement inquiries. For Rautio and Jokinen (2015), attending to snow pile children makes visible the limits of adult/educator/human attention: How do movements do (or scream, stretch, seek) the "I am not here (in the way you think I am)" or "let me be"? How might pedagogy attend to uncommon movements, and how might pedagogy need to become differently response-able to uncommon movements? Here, movement and ethics are deeply entangled.
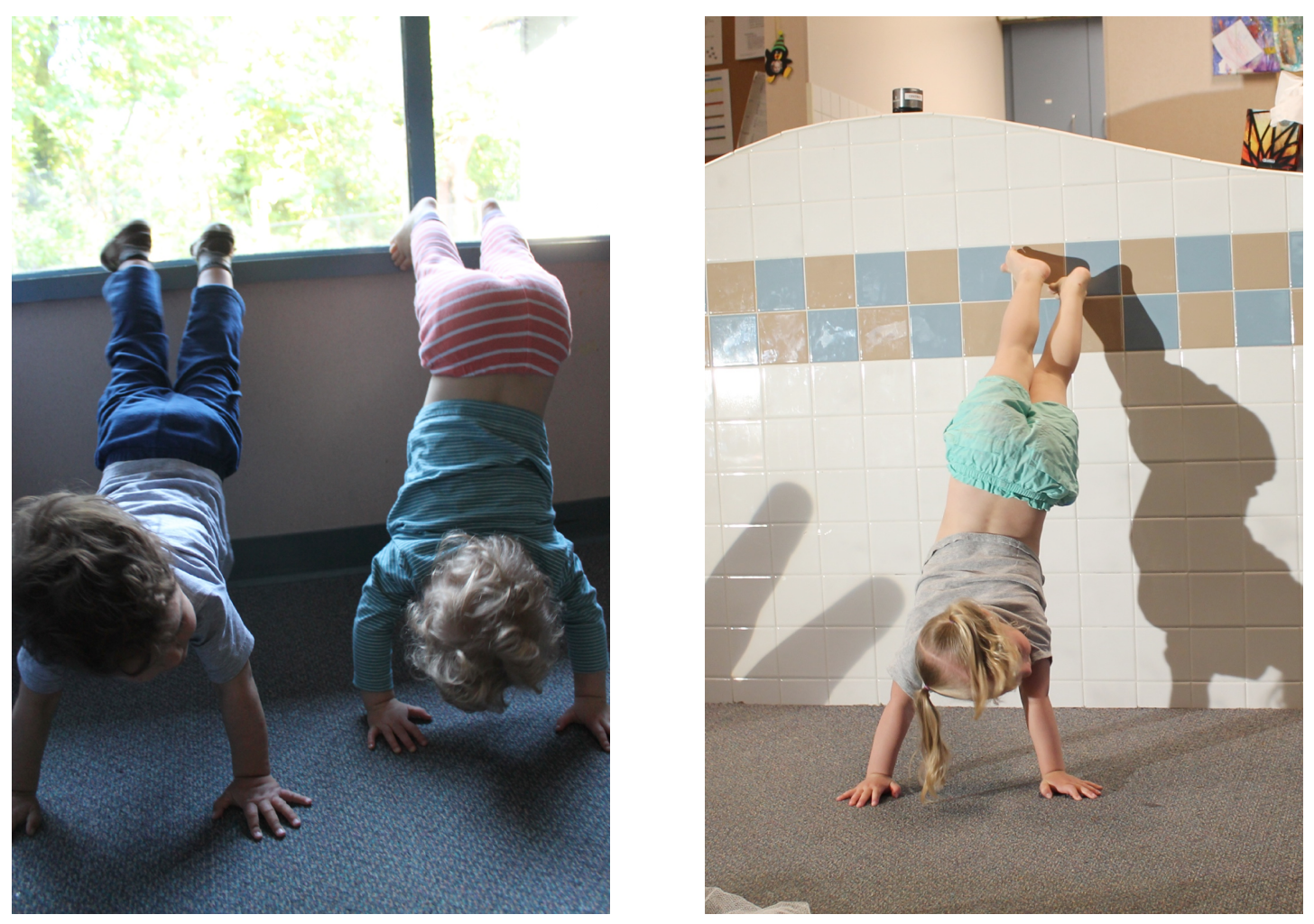

Figure 3. What might attending to common and uncommon movements produce?

Ildikó: I think it is definitely an educator's responsibility to make space for pedagogies to attend to uncommon movements. The biggest challenge is how we can encounter movement pedagogy histories respectfully while we make our moves to choose change. We have to be careful with appropriation or creating new "rules" for movement. Thinking about movements in early childhood settings, educators still have the luxury/chance/privilege to respectfully interpret early childhood frameworks in unique ways, which we learn from earlier experiences shared by educators, researchers, and children and policies. (How political is that itself?) We can be frontiers and we can have our continuing missions to explore strange new worlds, to seek out new life, new politics, and to boldly move where/how no one has gone before!

Nicole: This is an important reminder for me: Physical activity and physical literacy pedagogies do matter to Canadian and EuroWestern early childhood education. This analysis, and our inquiry work, does not intend to ignore this, but is relentless in contesting the supremacy of these movement discourses. This project is not a suggestion that movement is organic to childhood, nor does it engender motion as an enchanted balm against the regulatory governance of obesity, health, and physical activity discourses. Rather, we are making visible how, and why, we might think movement pedagogically.

For me, "getting grounded" is a literal ethical encounter with movement and pedagogy. It is pushing my palms, in collaboration with the children, into the prickly carpet, tracing the indents that the licensing-sanctioned flooring fibres leave on my white-settler skin, following the strength in my wrists up through my history as a hockey player in athlete development programs sustained by physical literacy discourses, and noticing the tensing of my shoulders as a response to problematic obesity and health rhetoric, while knowing that my muscles generate force in specific ways because of their participation in cycling classes borne of these health discourses. "Getting 
grounded" is taking the contested politics of movement as a provocation, not a prescription, for pedagogy and practice, an attention to how movement does politics, does ethics, and does pedagogy, and a demand that we be response-able, move-able, with the complexities of moving in contemporary Canadian early childhood education.

\section{Moving Provocations for Moving Pedagogies}

Thinking movement with pedagogy requires that we consider how different movements, and the differential consequences, relations, and politics they enact, might be relevant to children's lives in increasingly complex, contested, and controlled spaces of childhood. It demands that we imagine what moving pedagogies response-able to contemporary times might produce, while interrogating how mainstream movement pedagogies and policies constrain and enable different possibilities for moving.

Thinking movement pedagogically is a question of confronting physical literacy discourses that require children master ball-catching skills and redeploying these dictates as critical engagements with the potentiality of movement, a shift from "How do I teach this child to correctly catch a ball?" to "What might children-ball-catching relations do with pedagogy?" It demands that we make physical activity policies vulnerable as we reconceptualize the perceptibility of movement in early childhood, transforming questions of "How will ball catching fulfill our daily physical activity requirement?" to "How might children-ball-catching bodies enact politicized encounters with complex worlds?"

Movement matters with early childhood education pedagogies. But more than this, we argue for an attention to, and a politicized reengagement with, how movement matters with early childhood education.

\section{References}

Ashton, E. (2014). I've got my EYE on you: Schooled readiness, standardized testing, and developmental surveillance. Canadian Children, 39(1), 3-24.

Beausoleil, N., \& Ward, P. (2010). Fat panic in Canadian public health policy: Obesity as different and unhealthy. Radical Psychology, 8(1). Retrieved from: http://www.radicalpsychology.org/vol8-1/fatpanic.html

Berger, I. (2010). Extending the notion of pedagogical narration through Hannah Arendt's political thought. In V. Pacini-Ketchabaw (Ed.), Flows, rhythms, and intensities of early childhood education curriculum (pp. 57-76). New York, NY: Peter Lang.

Berger, I. (2015). Pedagogical narrations and leadership in early childhood education as thinking in moments of not knowing. Canadian Children, 40(1), 130-147.

Blaise, M. (2014). Interfering with gendered development: A timely intervention. International Journal of Early Childhood, 46(3), 317-326. doi:10.1007/s13158-014-0122-9

Blaise, M., Hamm, C., \& Iorio, J. M. (2016). Modest witness(ing) and lively stories: Paying attention to matters of concern in early childhood. Pedagogy, Culture, \& Society, 1-12. doi: 10.1080/14681366.2016.1208265

Canadian Society for Exercise Physiology. (n.d.). Canadian physical activity guidelines for the early years. Ottawa, ON: Author.

Chronic Disease Prevention Alliance of Canada. (n.d.). Collaborative action on childhood obesity, Phase 2: Healthy beginnings for preschoolers 2-5. Ottawa, ON: Author.

Clark, V., Pacini-Ketchabaw, V., \& Hodgins, D. (2014). Thinking with paint: Troubling settler colonialisms through early childhood art pedagogies. International Journal of Child, Youth, and Family Studies, 5(4.2), 751-781. doi: 10.18357/ijcyfs.clarkv.5422014

Dolphijn, R., \& van der Tuin, I. (2012). New materialism: Interviews \& cartographies. Ann Arbour, MI: Open Humanities Press.

Elliott, C. (2016). Find your greatness: Responsibility, policy, and the problem of childhood obesity. In J. Ellison, D. McPhail, \& 
W. Mitchinson (Eds.), Obesity in Canada: Critical perspectives [Google Play eBook version] (Chapter 10). Toronto, ON: University of Toronto Press.

Ellison, J., McPhail, D., \& Mitchinson, W. (2016). Obesity in Canada. In J. Ellison, D. McPhail, \& W. Mitchinson (Eds.), Obesity in Canada: Critical perspectives [Google Play eBook version] (Introduction). Toronto, ON: University of Toronto Press.

Evans, B. (2010). Anticipating fatness: Childhood, affect, and the preemptive "war on obesity." Transactions of the Institute of British Geographers, 35(1), 21-38. doi: 10.1111/j.1475-5661.2009.00363.x

Evans, J., \& Davies, B. (2012). Embodying policy concepts. Discourse: Studies in the Cultural Politics of Education, 33(5), 617-633. doi: $10.1080 / 01596306.2012 .696497$

Evans, J., \& Rich, E. (2011). Body policies and body pedagogies: Every child matters in totally pedagogised schools. Journal of Educational Policy, 26(3), 361-379. doi: 10.1080/02680939.2010.500399

Gard, M. (2016). Hearing noises and noticing silence: Towards a critical engagement with Canadian body weight statistics. In J. Ellison, D. McPhail, \& W. Mitchinson (Eds.), Obesity in Canada: Critical perspectives [Google Play eBook version] (Chapter 1). Toronto, ON: University of Toronto Press.

Government of British Columbia. (n.d.). BC child care sector occupational competencies. Victoria, BC: Ministry of Health \& Ministry of Children and Family Development.

Government of British Columbia. (2008). British Columbia early learning framework. Victoria, BC: Ministry of Health \& Ministry of Children and Family Development.

Government of British Columbia. (2016). Child care licensing regulation: Community care and assisted living act. Victoria, BC: Ministry of Health \& Ministry of Children and Family Development.

Guthman, J. (2011). Weighing in: Obesity, food justice, and the limits of capitalism. Los Angeles, CA: University of California Press.

Haraway, D. (2015). Anthropocene, capitalocene, plantationocene, chthulucene: Making kin. Environmental Humanities, 6, $159-165$. doi: $10.1215 / 22011919-3615934$

Healthy Active Living and Obesity Research Group. (2014-2016). Canadian assessment of physical literacy: Physical literacy screening tasks. Retrieved from: https://www.capl-ecsfp.ca/physical-literacy-screening-tasks/

Hodgins, D. (2012). Pedagogical narrations' potentiality as a methodology for child studies research. Canadian Children, 37(1), 4-11.

Hodgins, D., Kummen, K., Pacini-Ketchabaw, V., \& Thompson, D. (2013). Entangling and reconceptualizing research/practice binaries in laboratory schools in British Columbia. In R. Langford \& A. Di Santo (Eds.), Leading the way: Recognizing the role of early learning lab schools in Canadian universities and colleges (pp. 42-48). Retrieved from: http://www.ryerson.ca/content/dam/ ecs/news/events/General_Public/images/Leading_the_way_v2.pdf

Hultman, K., \& Lenz Taguchi, H. (2010). Challenging anthropocentric analysis of visual data: A relational materialist methodological approach to educational research. International Journal of Qualitative Studies in Education, 23(5), 525-542. doi: $10.1080 / 09518398.2010 .500628$

Jackson,A.Y.(2016).An ontology of a backflip. Cultural Studies Critical Methodologies, 16(2), 183-192. doi: 10.1177/1532708616634735

Kummen, K. (2011). Once upon a time there was a ready child: Challenging readiness as a single story. Child and youth care: Critical perspectives on pedagogy, practice, and policy (pp. 199-218). Vancouver, BC: UBC Press.

Kummen, K. (2014). When matter in the classroom matters: Encounters with race in pedagogical conversations. International Journal of Child, Youth, and Family Studies, 5(4.2), 808-825. doi: 10.18357/ijcyfs.kummenk.5422014 
Larsson, H., \& Quennerstedt, M. (2012). Understanding movement: A sociocultural approach to exploring moving humans. Quest, 64(4), 281-298. doi: 10.1080/00336297.2012.706884

LeBesco, K. (2011). Neoliberalism, public health, and the moral perils of fatness. Critical Public Health, 21(2), 153-164. doi: $10.1080 / 09581596.2010 .529422$

Lenz Taguchi, H. (2010). Going beyond the theory/practice divide in early childhood education: Introducing an intra-active pedagogy. London, England: Routledge.

Lenz Taguchi, H. (2011). Investigating learning, participation, and becoming in early childhood practices with a relational-materialist approach. Global Studies of Childhood, 1(1), 36-50. doi: 10.2304/gsch.2011.1.1.36

Lenz Taguchi, H., Palmer, A., \& Gustafsson, L. (2016). Individuating "sparks" and "flickers" of "a life" in dance practices with preschoolers: The "monstrous children" of Colebrook's queer vitalism. Discourse: Studies in the Cultural Politics of Education, 37(5), 705-716. doi: 10.1080/01596306.2015.1075710

Lundvall, S. (2015). Physical literacy in the field of physical education: A challenge and a possibility. Journal of Sport and Health Science, 4(2), 113-118. doi: 10.1016/j.jshs.2015.02.001

Mandigo, J., Francis, N., Lodewyk, K., \& Lopez, R. (2009). Physical literacy for educators. Physical Health \& Education Journal, 75(3), 27-30.

Manning, E. (2014). Wondering the world directly: Or, how movement outruns the subject. Body \& Society, 20(3\&4), 162-188. doi: $10.1177 / 1357034 X 14546357$

Markula, P. (2014). Reading yoga: Changing discourses of postural yoga on the Yoga Journal covers. Communication \& Sport, 2(2), 143-171. doi: $10.1177 / 2167479513490673$

Markula, P., \& Kennedy, E. (2011). Beyond binaries: Contemporary approaches to women and exercise. In P. Markula \& E. Kennedy (Eds.), Women and exercise: The body, health, and consumerism (pp. 1-26). New York, NY: Routledge.

Moss, P. (2016). Why can’t we get beyond quality? Contemporary Issues in Early Childhood, 17(1), 8-15. doi: 10.1177/1463949115627895

Nxumalo, F. (2015). Forest stories: Restorying encounters with "natural" places in early childhood education. In V. Pacini-Ketchabaw \& A. Taylor (Eds.), Unsettling the colonial places and spaces of early childhood education (pp. 21-42). New York, NY: Routledge.

Nxumalo, F. (2016). Storying practices of witnessing: Reconfiguring quality in everyday pedagogical encounters. Contemporary Issues in Early Childhood, 17(1), 39-53. doi: 10.1177/1463949115627898

Nyberg, G., \& Larsson, H. (2014). Exploring "what" to learn in physical education. Physical Education and Sport Pedagogy, 19(2), 123-135. doi: 10.1080/17408989.2012.726982

Osgood, J., Scarlett, R. R., \& Giugni, M. (2015). Reconfiguring quality: Beyond discourses and subjectivities to matter, bodies, and becomings in early childhood education. In G. S. Cannella, M. Salazar Perez, \& I. Lee (Eds.), Critical examinations of quality in early education and care (pp. 139-156). New York, NY: Peter Lang.

Pacini-Ketchabaw, V., \& Nxumalo, F. (2015). Unruly raccoons and troubled educators: Nature/culture divides in a child care center. Environmental Humanities, 7, 151-168. doi: 10.1215/22011919-3616380

Pacini-Ketchabaw, V., Nxumalo, F., Kocher, L., Elliott, E., \& Sanchez, A. (2015). Journeys: Complexifying early childhood practices through pedagogical narration. Toronto, ON: University of Toronto Press.

Pacini-Ketchabaw, V., Taylor, A., \& Blaise, M. (2016). Decentering the human in multispecies ethnographies. In C. A. Taylor \& C. 
Hughes (Eds.), Posthuman research practices in education (pp. 149-167). London, England: Palgrave Macmillan.

Pacini-Ketchabaw, V., Kind, S., \& Kocher, L. (2016). Encounters with materials in early childhood education. New York, NY: Routledge.

ParticipACTION. (2016). Thought leadership: Benefits and guidelines for the early years 0-4. Toronto, ON: Author. Retrieved from: https://www.participaction.com/en-ca/thought-leadership/benefits-and-guidelines/0-4

Petherick, L., \& Beausoleil, N. (2016). Obesity panic, body surveillance, and pedagogy: Elementary teachers' response to obesity messaging. In J. Ellison, D. McPhail, \& W. Mitchinson (Eds.), Obesity in Canada: Critical perspectives [Google Play eBook version] (Chapter 9). Toronto, ON: University of Toronto Press.

Rail, G. (2012). The birth of the obesity clinic: Confessions of the flesh, biopedagogies, and physical culture. Sociology of Sport Journal, $29,227-253$.

Rautio, P., \& Jokinen, P. (2015). Children's relations to the more-than-human world beyond developmental views. In B. Evans, J. Horton, \& T. Skelton (Eds.), Play and recreation, health and well being (pp. 35-49). Singapore: Springer.

Rice, C. (2007). Becoming "the fat girl": Acquisition of an unfit identity. Women's Studies International Forum, 30, 158-174. doi: 10.1016/j.wsif.2007.01.001

Rice, C. (2016). Revisioning fat: From enforcing norms to exploring possibilities unique to different bodies. In J. Ellison, D. McPhail, \& W. Mitchinson (Eds.), Obesity in Canada: Critical perspectives [Google Play eBook version] (Chapter 16). Toronto, ON: University of Toronto Press.

Rich, E. (2011). "I see her being obesed!": Public pedagogy, reality media, and the obesity crisis. Health, 15(1), 3-21. doi: $10.1177 / 1363459309358127$

Rotas, N. (2015). Running ecologies: Thinking movement pedagogically. Inflexions, 8, 185-189.

Sport for Life Society. (2016). Long term athlete development model. Ottawa, ON: Author.

Springgay, S., \& Rotas, N. (2015). How do you make a classroom operate like a work of art? Deleuzeguattarian methodologies of researchcreation. International Journal of Qualitative Studies in Education, 28(4), 552-572. doi: 10.1080/09518398.2014.933913

Springgay, S., \& Rotas, N. (2015). How do you make a classroom operate like a work of art? Deleuzeguattarian methodologies of researchcreation. International Journal of Qualitative Studies in Education, 28(4), 552-572. doi: 10.1080/09518398.2014.933913

St. Pierre, E. A., Jackson, A. Y., \& Mazzei, L. A. (2016). New empiricisms and new materialisms: Conditions for new inquiry. Cultural Studies Critical Methodologies, 16(2), 99-110. doi: 10.1177/1532708616638694

Taylor, A., Blaise, M., \& Giugni, M. (2013). Haraway's "bag lady story-telling": Relocating childhood and learning within a "posthuman landscape." Discourse: Studies in the Cultural Politics of Education, 34(1), 48-62. doi: 10.1080/01596306.2012.698863

Taylor, A., \& Pacini-Ketchabaw, V. (2015). Learning with children, ants, and worms in the Anthropocene: Towards a common world pedagogy of multispecies vulnerability. Pedagogy, Culture, \& Society, 25(4), 507-529. doi: 10.1080/14681366.2015.1039050

Temple, V., \& Preece, A. (2007). Healthy opportunities for preschoolers. Vancouver, BC: Legacies Now.

Tremblay, M., \& Lloyd, M. (2010). Physical literacy measurement: The missing piece. Physical Health \& Education Journal, 76(1), 26-30.

Wiest, A. L., Andrews, D. L., \& Giardina, M. D. (2015). Training the body for healthism: Reifying vitality in and through the clinical gaze of the neoliberal fitness club. Review of Education, Pedagogy, and Cultural Studies, 37(1), 21-40. doi: 10.1080/10714413.2015.988505 